\title{
Recognizing two new Hippolyte species (Decapoda, Caridea, Hippolytidae) from the South China Sea based on integrative taxonomy
}

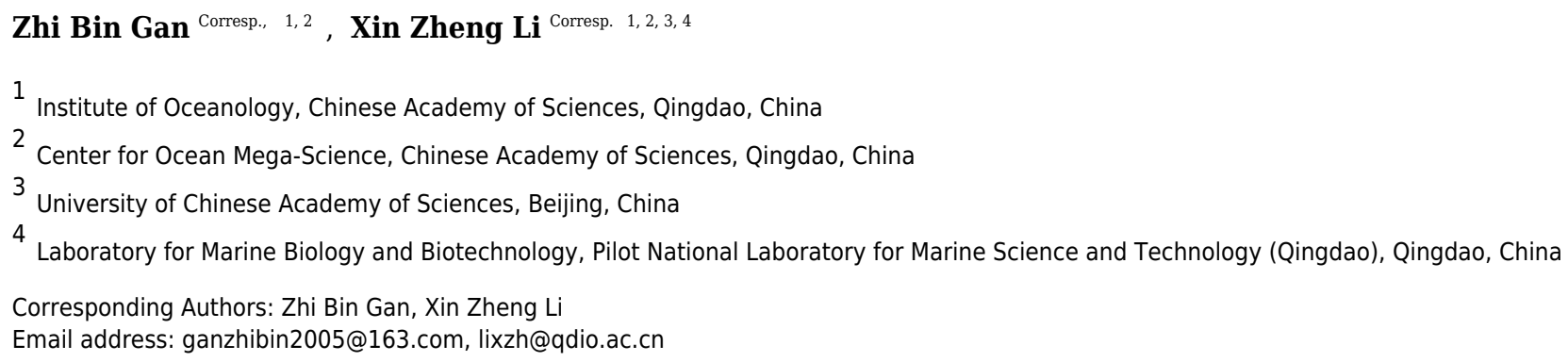

Hippolyte shrimps exhibit abundant biological diversity and display great ecological significance in seaweed bed ecosystems. Dozens of Hippolyte specimens were collected from Hainan Island and the Xisha Islands in the South China Sea. Detailed examination indicates that some of these specimens represent new Hippolyte species. Based on morphological, genetic, and ecological data, $H$. chacei sp. nov. and $H$. nanhaiensis sp. nov. are described. $H$. chacei sp. nov. was collected from the Sargassum sp. biotope in Hainan Island and is distinguished from congeners by its unique mandible and the dactylus of the third to fifth pereiopods; this species has a basal position in the Indo-West Pacific species clade in the phylogenetic tree which is reconstructed based on 16S rRNA gene. $\mathrm{H}$. nanhaiensis sp. nov. was collected from the biotopes of Galaxaura sp. or Halimeda sp. in the Xisha Islands, and it differs from congeners in series of characters associated with rostrum, scaphocerite, antennular peduncle, and spines on the dactylus of the third to fifth pereiopods. Additionally, it is sister to $H$. australiensis in the phylogenetic tree. A key to identify mature female Hippolyte species of the Indo-West Pacific and neighboring seas is provided. 


\section{Recognizing two new Hippolyte species (Decapoda,}

2 Caridea, Hippolytidae) from the South China Sea

3 based on integrative taxonomy

4

Zhi Bin Gan ${ }^{1,2}$, Xin Zheng Li ${ }^{1,2,3,4}$

${ }^{1}$ Institute of Oceanology, Chinese Academy of Sciences, Qingdao, China

${ }^{2}$ Center for Ocean Mega-Science, Chinese Academy of Sciences, Qingdao, China

${ }^{3}$ University of Chinese Academy of Sciences, Beijing, China

${ }^{4}$ Laboratory for Marine Biology and Biotechnology, Pilot National Laboratory for Marine Science and Technology (Qingdao), Qingdao, China

Corresponding Authors

Xin Zheng Li

lixzh@qdio.ac.cn

Zhi Bin Gan

ganzhibin2005@163.com

\section{Abstract}

Hippolyte shrimps exhibit abundant biological diversity and display great ecological significance in seaweed bed ecosystems. Dozens of Hippolyte specimens were collected from Hainan Island and the Xisha Islands in the South China Sea. Detailed examination indicates that some of these specimens represent new Hippolyte species. Based on morphological, genetic, and ecological data, $H$. chacei sp. nov. and $H$. nanhaiensis sp. nov. are described. $H$. chacei sp. nov. was collected from the Sargassum sp. biotope in Hainan Island and is distinguished from congeners by its unique mandible and the dactylus of the third to fifth pereiopods; this species has a basal position in the Indo-West Pacific species clade in the phylogenetic tree which is reconstructed based on 16S rRNA gene. H. nanhaiensis sp. nov. was collected from the biotopes of Galaxaura sp. or Halimeda sp. in the Xisha Islands, and it differs from congeners in series of characters associated with rostrum, scaphocerite, antennular peduncle, and spines on the dactylus of the third to fifth pereiopods. Additionally, it is sister to H. australiensis in the phylogenetic tree. A key to identify mature female Hippolyte species of the Indo-West Pacific and neighboring seas is provided.

\section{Introduction}

Shrimps of the genus Hippolyte Leach, 1814 display high diversity in morphology, coloration, and ecological habits. They occur mainly in tropical and temperate oceans, although some species, such as $H$. varians Leach, 1814, are known from the Arctic Circle (D'Udekem d'Acoz, 
40

41

42

43

44

45

46

47

48

49

50

51

52

53

54

55

56

57

58

59

60

61

62

63

64

65

66

67

68

69

70

71

72

73

74

75

76

77

78

79

2007). Most Hippolyte species inhabit seaweed beds, but some are obligate or facultative symbionts of other organisms, such as gorgonians and crinoids (D'Udekem d'Acoz, 2007; Marin et al., 2011). The taxonomy, phylogeny, and biology of Hippolyte taxa have attracted considerable attention in recent years (Manjón-Cabeza et al., 2011; Marin et al., 2011; Terossi \& Mantelatto, 2012; Liasko et al., 2015; Duarte \& Flores, 2017; Duarte et al., 2017; Gan \& Li, 2017a; 2017b; Liasko et al., 2017; Terossi et al., 2017). Currently, a total of 35 valid species are recognized worldwide (D'Udekem d'Acoz, 1996; 2007; De Grave \& Fransen, 2011; Marin et al., 2011; Gan \& Li, 2017a, 2017b; Terossi et al., 2017), of which about 12 species occur in the Indo-West Pacific region. Additional unnamed and cryptic species have been reported (Hayashi, 1986; D’Udekem d'Acoz, 1996; 2007; Terossi et al., 2017).

Due to its morphological diversity and characters overlap, and the complexity of information in published literature, taxonomic research of Hippolyte based on morphological characters is difficult (D’Udekem d'Acoz, 1996; Gan \& Li, 2017a). The situation is particularly complicated in a complex of species referred to ' $H$. ventricosa H. Milne Edwards, 1837', including: $H$. acuta (Stimpson, 1860), H. australiensis (Stimpson, 1860), H. ngi Gan \& Li, 2017, H. singaporensis Gan \& Li, 2017, H. ventricosa H. Milne Edwards, 1837, and Hippolyte sp. A from Australia, Hippolyte sp. B from Hawaii, Hippolyte sp. C from the Malay Archipelago, and Hippolyte sp. D from Madagascar (D’Udekem d'Acoz, 1996; Gan \& Li, 2017a, 2017b). Genetic analysis (Terossi et al., 2017) has also recently detected four cryptic or pseudocryptic species referred to: $H$. ventricosa group-sp. 1 and sp. 2 from Indonesia, $H$. ventricosa group-sp. 3 from Fiji, and $H$. ventricosa group-sp. 4 from Taiwan, all with morphological features closely similar to $H$. ventricosa redescribed by D'Udekem d'Acoz (1999).

During recent biodiversity surveys of the Hainan and Xisha islands (2014-2018) in the South China Sea, dozens of Hippolyte specimens were collected. After detailed examination and multiple analyses, we described two new species of the ' $H$. ventricosa H. Milne Edwards, 1837' species complex based on integrative methods.

\section{Materials \& Methods}

Sample collection and morphological examination. The information on biodiversity surveys are listed in Table 1. Although seaweed beds and coral reefs were sampled, species of Hippolyte were found only among algae and sea grass (Sargassum sp., Zostera sp., Galaxaura sp., and Halimeda sp.). All specimens were collected using handheld nets while snorkeling. After being photographed, specimens were preserved in 95\% ethanol. Dissection and illustrations were carried out using Nikon stereo- and compound microscopes (SMZ 1500 and AZ100). Measurements and length ratios were calculated following D'Udekem d'Acoz (1996). All specimens are deposited in the Marine Biological Museum of the Chinese Academy of Sciences (MBM), in the Institute of Oceanology of Chinese Academy of Sciences, Qingdao, China (IOCAS).

Molecular data and analysis. Total genomic DNA was extracted from pleopods of specimens using a QIAamp DNA Mini Kit (QIAGEN, Germany), following manufacturer 
80 instructions. Extracted DNA was eluted in $100 \mu \mathrm{l}$ of double-distilled $\mathrm{H}_{2} \mathrm{O}\left(\mathrm{ddH}_{2} \mathrm{O}\right)$. Partial 81 sequences of 16S rRNA genes were amplified from the diluted DNA via polymerase chain 82 reaction (PCR). Reactions were carried out in a 50- $\mu$ l volume containing: $25 \mu 1$ Premix Taq 83 (TaKaRa Taq ${ }^{\mathrm{TM}}$ Version 2.0 plus dye, Japan), $1 \mu \mathrm{l}$ each of forward and reverse primers $(10 \mu \mathrm{M})$ 84 respectively, $3 \mu \mathrm{l}$ DNA template, and $20 \mu \mathrm{l} \mathrm{ddH}_{2} \mathrm{O}$. Primers 16S-AR/1472 (5'85 CGCCTGTTTATCAAAAACAT-3'/5'-AGATAGAAACCAACCTGG-3') was used (Crandall \& 86 Fitzpatrick, 1996). The PCR profile involved: $3 \mathrm{~min}$ at $94^{\circ} \mathrm{C}$ for initial denaturation, 35 cycles of 87 denaturation at $94^{\circ} \mathrm{C}$ for $30 \mathrm{~s}$, annealing at $52^{\circ} \mathrm{C}$ for $40 \mathrm{~s}$, elongation at $72^{\circ} \mathrm{C}$ for $50 \mathrm{~s}$, and final 88 extension at $72^{\circ} \mathrm{C}$ for $10 \mathrm{~min}$. PCR products were purified using a QIAquick Gel Extraction Kit 89 90 91 (QIAGEN, Germany), and bidirectionally sequenced using the same primers with an ABI 3730xl Analyzer (Applied Biosystems, USA). Sequences were checked and proofread by ContigExpess 6.0 (a component of the Vector NTI Suite 6.0).

In addition to sequences obtained by PCR (Table 2, Dataset S1), we downloaded Hippolyte sequences from Genbank, including those previously reported cryptic or pseudocryptic taxa namely $H$. ventricosa group-sp. 1 (KX588914), $H$. ventricosa group-sp. 2 (KX588915), $H$. ventricosa group-sp. 3 (KX588915), and H. ventricosa group-sp. 4 (KX588915) of Terossi et al. (2017), and H. ventricosa group-sp. 5 (KF023090) of De Grave et al. (2014).

Molecular data (Dataset S2), including 37 sequences of 16S rRNA genes, were aligned using MUSCLE 3.8 (Edgar, 2004). Highly divergent and poorly aligned sites were omitted from alignment according to Gblocks $0.91 \mathrm{~b}$ (Castresana, 2000). The best-fitting nucleotide base substitution model $(\mathrm{GTR}+\mathrm{I}+\mathrm{G})$ for the alignment data was determined by Modeltest 3.7 (Posada \& Crandall, 1998). A maximum likelihood (ML) tree was constructed using PhyML 3.1 (Guindon \& Gascuel, 2003) with 1000 bootstrap reiterations. A Bayesian inference (BI) tree was constructed using MrBayes 3.2 (Huelsenbeck \& Ronquist, 2001). Markov chains were run for 2,000,000 generations, sampled every 2,000 generations; the first 25\% trees were discarded as

105

106

107

108

109

110

111

112

113

114

115

116

117

118

119

burn-in, after which remaining trees were used to construct the $50 \%$ majority-rule consensus tree and to estimate posterior probabilities. Genetic distances were calculated using the Kimura 2parameter (K2P) model in MEGA 7.0 (Kumar et al., 2016).

Ecological data. The biotope (mainly the algal colony) in which a shrimp lived was recorded on capture.

The following abbreviations are used: CL, carapace length, the length from the posterior orbital margin to the posterior dorsal border of the carapace; Coll., collector (s).

The electronic version of this article in Portable Document Format (PDF) will represent a published work according to the International Commission on Zoological Nomenclature (ICZN), and hence the new names contained in the electronic version are effectively published under that Code from the electronic edition alone. This published work and the nomenclatural acts it contains have been registered in ZooBank, the online registration system for the ICZN. The ZooBank LSIDs (Life Science Identifiers) can be resolved and the associated information viewed through any standard web browser by appending the LSID to the prefix http://zoobank.org/. The LSID for this publication is urn:lsid:zoobank.org:pub:1186ACB4-410C-4061-BE93-97CE040F0702. 
120 The online version of this work is archived and available from the following digital repositories:

121 PeerJ, PubMed Central and CLOCKSS.

\section{Results}

123 Taxonomy

124 Order Decapoda Latreille, 1802

125 Family Hippolytidae Spence Bate, 1888

126 Genus Hippolyte Leach, 1814

127 Hippolyte chacei sp. nov.

128 (Figs. 1-4, 5A)

129

130

131

132

133

134

135

136

137

138

139

140

141

142

143

144

145

146

147

148

149

150

151

152

153

154

155

156

157

158

159

Material examined. Holotype: MBM285015, non-ovigerous female, $3.3 \mathrm{~mm} \mathrm{CL}$, Hongtang bay, Hainan Island, northern South China Sea, 1-3 m, Coll. Z B, Gan, 25 March 2018 (GenBank accession number of 16S rRNA gene: MK231007). Paratypes: MBM285016, 1 male, $2.3 \mathrm{~mm}$ CL, same collection data as holotype (GenBank accession number of 16S rRNA gene: MK231008); MBM285017, 2 non-ovigerous female, 2.7-3.0 mm CL, Houhai bay, Hainan Island, northern South China Sea, 2-3 m, Coll. Z B. Gan, 22 March 2018.

Description. Outline robust (Fig. 1). Ratio lateral length/height of carapace 1.56-1.72. Rostrum long, slightly shorter than carapace, distinctly overreaching antennular peduncle, nearly reaching to the end of scaphocerite. Rostrum without lateral carina, superior border slightly concaved, unarmed in the female specimens (Fig. 2A,B) and armed with only one proximal tooth in the male specimen (Fig. 2C); inferior border slightly convex, armed with 4 teeth in the distal half length. Carapace smooth and glabrous, location of supraorbital spine behind of the posterior orbital margin; tip of antennal spine slightly overreaching inferior orbital angle; tip of hepatic spine falling short of anterior edge of carapace. Inferior orbital angle strongly produced, knoblike (Fig. 2B,D). Branchiostegal margin with a distinct notch. Pterygostomian region rounded, strongly produced (Fig. 1,2B).

Abdominal segments smooth (Fig. 1). Third abdominal segment geniculately curved. Ratio dorsal length/height of the sixth abdominal segment 1.95-2.10. Telson (Fig. 2E) longer than the sixth abdominal segment, posterior margin rounded, armed with 8 strong spines, outer spines smallest, medial two longest, without intermediate spinule or seta; dorsal surface armed with 2 pairs of spines situated on distal $0.31-0.35$ and $0.59-0.63$ telson length.

Eye (Fig. 2A) well developed, tip of cornea nearly reaching to the end of first segment of antennular peduncle when extended forward; unpigmented part of eyestalk longer than broad; cornea semispherical, distinctly shorter than unpigmented part of eyestalk.

Antennular peduncle (Fig. 2F) slightly overreaching mid-length of scaphocerite. First segment of antennular peduncle with one well developed distolateral tooth, inner ventral tooth (Fig. 2G) on $0.47-0.50$ of first segment (excluding distolateral tooth). Stylocerite robust, reaching to $0.56-$ 0.62 (distolateral tooth included), or $0.69-0.75$ (distolateral tooth excluded) of first segment. Second segment of antennular peduncle $0.81-0.86$ times as long as broad in dorsal view, approximately $0.86-0.98$ times as long as third segment in dorsal view. Outer antennular flagellum shorter than inner one and proximal 6-8 segments thicker than distal ones. 
160 Scaphocerite (Fig. 2H) 3.06-3.18 times as long as wide, distolateral spine of scaphocerite far

161

162

163

164

165

166

167

168

169

170

171

172

173

174

175

176

177

178

179

180

181

182

183

184

185

186

187

188

189

190

191

192

193

194

195

196

197

198

199

from reaching distal margin of blade, distolateral spine and blade separated by a distinct notch.

Mandible (Fig. 3A,B) without palp, incisor process with 15-17 acute teeth. Maxillula (Fig. 3C) with broad curved palp, distal margin of upper lacinia armed with 14-18 spines and scattered simple long setae. Maxilla (Fig. 3D) with short palp, scaphognathite broad and long, lateral border nearly straight; inner lacinia bilobed, distal margin furnished with row of spines and long plumose setae; proximal endite round, with long setae on distal margin. Epipod of first maxilliped (Fig. 3E) slightly bilobed; endopod broad, with distal long setae; exopod welldeveloped, caridean lobe broad. Second maxilliped (Fig. 3F) with well-developed exopod, flagelliform; endopod normal, dactylar segment oval, terminal margin furnished with simple and spinous setae; propodal segment with anteromedial margin round, bearing simple setae; carpus broader than long, shorter than merus; ischium and basis fused. Third maxilliped (Fig. 3G) reaching to $0.32-0.39$ of scaphocerite when extended forward; exopod relatively short, only reaching to the mid-length of antepenultimate segmentof endopod; ultimate segment (excluding apical spine) of endopod 1.23-1.32 times as long as penultimate segment, distal half armed with 7-9 strong spines; antepenultimate segment nearly equal length to the last two segments combined.

First pereiopod (Fig. 4A) shortest among pereiopods, robust and oblique, reaching to the end of basicerite when extended forward. Ventral margin of ischium, merus and carpus furnished with long simple setae. Terminal margin of carpus cotyloid. Cutting edges of chela nondenticulate, outer margin of fingers with long simple setae, tip of fingers armed with 3 acute spines respectively (Fig. 4B).

Second pereiopod (Fig. 4C) slightly overreaching the end of third maxilliped when extended forward. Carpus with 3 subsegments, first subsegment 1.70-1.85 times as long as second subsegment, third subsegment slightly longer than or subequal to first subsegment; first subsegment 2.45-2.56 times as long as wide, second subsegment 1.08-1.12 times as long as wide, third subsegment 2.06-2.12 times as long as wide. Cutting edges of chela not denticulate, outer margin of fingers with long simple setae, tip of fixed finger and dactylus armed with 3 acute spines respectively (Fig. 4D).

Third to fifth pereiopods long and robust. Third pereiopod (Fig. 4E) reaching to the distolateral spine of scaphocerite when extended forward; dactylus with 13-16 spines, the last 23 subdorsal spines distinctly shorter than the neighbouring ones (Fig. 4F); propodus 5.56-5.62 times as long as wide, armed with 6-7 pairs of spines on ventral margin; carpus 2.66-2.73 times as long as wide, armed with one proximal lateral spine; merus 5.58-5.62 times as long as wide, armed with 3 lateral spines. Ratio length of third pereiopod dactylus with longest apical spine/length of propodus $0.45-0.49$; ratio length of third pereiopod dactylus with longest apical spine/length of carpus $0.79-0.83$; ratio length of dactylus without spines/breadth of dactylus without spines 2.61-2.69; ratio length of dactylus with longest spines/breadth of dactylus without spines 2.95-3.10; ratio length of longest spine of dactylus/breadth of dactylus without spines $0.62-0.71$; ratio length of longest spine of dactylus/length of dactylus without spines $0.22-0.28$.

Peer] reviewing PDF | (2018:11:33158:3:0:NEW 3 Feb 2019) 
200

201

202

203

204

205

206

207

208

209

210

211

212

213

214

215

216

217

218

219

220

221

222

223

224

225

226

227

228

229

230

231

232

233

234

235

236

237

238

239

240

Third pereiopod (Fig. 4G,H) of male specimen with propodus and dactylus forming a prehensile apparatus. Fourth and fifth pereiopods (Fig. 4I,J,K,L) similar in shape to third pereiopod of female specimen, but slightly decreasing in size. Merus of fourth pereiopod armed with 2 lateral spines; merus of fifth pereiopod without lateral spine.

First pleopod (Fig. 4M) of female specimen normal, endopod about 0.54-0.62 times as long as exopod. First pleopod (Fig. 4N) of male specimen with endopod about $0.41-0.46$ times as long as exopod. Second pleopod (Fig. 4O) of male specimen with endopod about 0.81-0.89 times as long as exopod, appendix masculina with 9 apical setae, about 0.39-0.43 times as long as appendix interna (Fig. 4P).

Coloration. Generally light brown over body (Fig. 5A), with few tawny stripes on carapace and faint tawny spots on abdomen.

Biotope. All specimens were captured among gulfweed (Sargassum sp.) at depths of 1-3 m. Numerous Hippolyte cf. ventricosa were captured simultaneously.

Distribution. Hongtang and Houhai bays, Hainan Island, northern South China Sea. Presumably, this species also occurs in Malayan Archipelago and Madagascar (see discussion).

Etymology. The new species is named after Dr. Fenner A. Chace, Jr. in recognition of his great contribution to the crustacean taxonomy.

\section{Hippolyte nanhaiensis sp. nov.}

\section{(Figs. 6-9, 5B-E)}

Material examined. Holotype: MBM285018, ovigerous female, $1.6 \mathrm{~mm}$ CL, Ganquan Island, Xisha Islands, the South China Sea, 1-3 m, Coll. Z B, Gan, 15 May 2015 (GenBank accession number of 16S rRNA gene: MK231005). Paratypes: MBM285019, 1 male, $1.1 \mathrm{~mm}$ CL, same collection data as holotype (GenBank accession number of 16S rRNA gene: MK231006); MBM189210, 4 ovigerous female, 1.3-1.6 mm CL, 2 female, 1.2-1.3 mm CL, 2 male, 0.9-1.1 mm CL, 1 juvenile $0.6 \mathrm{~mm} \mathrm{CL}$, same collection data as holotype; MBM189211, 19 ovigerous female, 1.3-1.9 mm CL, 6 female, 1.0-1.4 mm CL, 5 male, 0.8-1.1 mm CL, 5 juvenile 0.6-0.8 mm CL, Bei Island, Xisha Islands, the South China Sea, 1-3 m, Coll. Z B. Gan, 13 May 2015.

Description. Outline stout (Fig. 6). Ratio lateral length/height of carapace 1.49-1.58. Rostrum distinctly shorter than carapace, reaching to or slightly overreaching the end of antennular peduncle. Rostrum without lateral carina, superior border straight, armed with 1 or 2 teeth in proximal position (Fig. 7A-D); inferior border armed with 1 subdistal tooth in female specimens (Fig. 7C), unarmed or only with a tiny distal notch in male specimens (Fig. 7D). Carapace smooth and glabrous. Location of supraorbital spine behind of the posterior orbital margin. Antennal spine small, slightly overreaching inferior orbital angle. Hepatic spine reaching to or slightly overreaching anterior edge of carapace. Inferior orbital angle produced, knob-like (Fig. 7B,C). Branchiostegal margin sinuous. Pterygostomian region rounded, strongly produced (Fig. 7C).

Abdominal segments smooth (Fig. 6), without or with few long plumose setae on tergum. Third abdominal segment geniculately curved. Ratio dorsal length/height of the sixth abdominal segment 1.91-2.08. Telson (Fig. 7E) longer than sixth abdominal segment, posterior margin 
241 rounded, armed with 8 strong spines, outer spines smallest, medial two longest, without or with 2 242 intermediate long plumose setae; dorsal surface armed with 2 pairs of spines situated on distal $243 \quad 0.21-0.26$ and $0.43-0.49$ telson length.

244 Eye (Fig. 7A) well developed, tip of cornea falling short of the first segment of antennular 245 peduncle when extended forward; unpigmented part of eyestalk slightly longer than broad;

246 247

248

249

250

251

252

253

254

255

256

257

258

259

260

261

262

263

264

265

266

267

268

269

270

271

272

273

274

275

276

277

278

279 cornea semispherical, slightly shorter than unpigmented part of eyestalk.

Antennular peduncle (Fig. 7F) distinctly overreaching mid-length of scaphocerite. First segment of antennular peduncle with one distolateral tooth; inner ventral tooth (Fig. 7G) on $0.59-0.66$ of first segment (excluding distolateral tooth), small. Stylocerite robust, reaching to 0.86-0.92 (distolateral tooth included), or 0.76-0.81 (distolateral tooth excluded) of first segment. Second segment of antennular peduncle 0.88-0.96 times as long as broad in dorsal view, 0.83-0.95 times as long as third segment. Outer antennular flagellum shorter than inner one and proximal 7-9 segments thicker than distal ones. Scaphocerite (Fig. 7H) 2.19-2.38 times as long as wide, distolateral spine of scaphocerite far from reaching distal margin of blade, distolateral spine and blade separated by a notch.

Mouthparts with morphology typical for the genus Hippolyte. Mandible (Fig. 8A) without palp, incisor process with 5 acute teeth. Maxillula (Fig. 8B) with curved palp, distal margin of upper lacinia armed with 8-10 spines and 2 long plumose setae. Maxilla (Fig. 8C) with short palp; scaphognathite broad in upper half and narrow in lower half, lateral border nearly straight; inner lacinia bilobed, distal margin furnished with spinous setae; proximal endite round, with long plumose setae on distal margin. Endopod of first maxilliped (Fig. 8D) slender, with long plumose setae; exopod with feeble caridean lobe on base. Second maxilliped (Fig. 8E) with welldeveloped exopod, flagelliform; endopod normal, dactylar segment arched, terminal margin armed with row of long spines; propodal segment bearing few long plumose setae; carpus longer than broad, shorter than merus. Third maxilliped (Fig. 8F) reaching to mid-length of scaphocerite when extended forward; exopod reaching to $0.72-0.79$ of antepenultimate segment; ultimate segment (excluding apical spine) of endopod 1.61-1.78 times as long as penultimate segment, distal half armed with 6-9 strong spines; antepenultimate segment slightly shorter than the last two segments combined.

First pereiopod (Fig. 9A) shortest among pereiopods, oblique, nearly reaching to mid-length of the scaphocerite when extended forward. Ventral margin of basis, ischium, and merus furnished with long plumose setae. Terminal margin of carpus cotyloid. Cutting edges of chela nondenticulate, outer margin of fingers with long simple setae, tip of fixed finger with 3 acute spines, tip of dactylus with 4 acute spines (Fig. 9B).

Second pereiopod (Fig. 9C) slightly overreaching the distolateral spine of scaphocerite when extended forward. Carpus with 3 subsegments, first subsegment 2.13-2.26 times as long as second subsegment, third subsegment slightly shorter than first subsegment; first subsegment 2.65-2.76 times as long as wide, second subsegment 1.08-1.16 times as long as wide, third subsegment 1.76-1.83 times as long as wide. Cutting edges of chela not denticulate, outer 
280

281

282

283

284

285

286

287

288

289

290

291

292

293

294

295

296

297

298

299

300

301

302

303

304

305

306

307

308

309

310

311

312

313

314

315

316

317

318

319

margin of fingers with long simple setae, tip of fixed finger with 3 acute spines, tip of dactylus with 4 acute spines (Fig. 9D).

Third to fifth pereiopods long and robust. Third pereiopod (Fig. 9E) reaching beyond terminal blade of scaphocerite by dactylus when extended forward; dactylus with 8-10 spines, all spines in ventral and apical position (none in dorsal or subdorsal position), with 2 apical spines larger than others (the ultimate one longer but thinner than the penultimate one) (Fig. 9F); propodus 6.98-7.12 times as long as wide, armed with 4-6 pairs of spines on ventral margin; carpus 2.963.14 times as long as wide, armed with one proximal lateral spine; merus 6.45-6.63 times as long as wide, armed with 2 lateral spines. Ratio length of third pereiopod dactylus with longest apical spine/length of propodus $0.42-0.46$; ratio length of third pereiopod dactylus with longest apical spine/length of carpus $0.86-0.92$; ratio length of dactylus without spines/breadth of dactylus without spines 2.86-2.93; ratio length of dactylus with longest spines/breadth of dactylus without spines 4.35-4.43; ratio length of longest spine of dactylus/breadth of dactylus without spines $1.50-1.55$; ratio length of longest spine of dactylus/length of dactylus without spines $0.53-0.58$. Third pereiopod of male specimen with propodus and dactylus forming a prehensile apparatus (Fig. 9G,H). Fourth and fifth pereiopods (Fig. 9I,J) similar in shape to third pereiopod of female specimen, but slightly decreasing in size. Merus of fourth pereiopod armed with $0-1$ lateral spine, merus of fifth pereiopod without lateral spine.

First pleopod (Fig. 9K) of female specimen normal, endopod about $0.72-0.78$ times as long as exopod. First pleopod (Fig. 9L) of male specimen with endopod about $0.25-0.29$ times as long as exopod. Second pleopod (Fig. 9M) of male specimen with endopod about $0.79-0.86$ times as long as exopod; appendix masculina with 8 apical setae, about $0.41-0.47$ times as long as appendix interna (Fig. 9N).

Coloration and Biotopes. Specimens collected from different biotopes manifested different body colors. Specimens (Fig. 5B,C) captured among Galaxaura sp. were generally pink over body, with numerous white spots; specimens (Fig. 5D,E) captured among Halimeda sp. were generally light green over body, with white or pink stains on the carapace, abdomen, and telson. All specimens were captured from 1 to $3 \mathrm{~m}$ depth.

Distribution. Xisha Islands, South China Sea. Presumably, this species also occurs in Taiwan Island (see discussion).

Etymology. 'Nanhai' means the South China Sea; the new species is named after its type locality.

\section{Hippolyte cf. ventricosa H. Milne Edwards, 1837}

\section{(Figs. 5F-G)}

Material examined. MBM189209, ovigerous female, $4.9 \mathrm{~mm}$ CL, Houhai bay, Hainan Island, northern South China Sea, 1-3 m, Coll. Z B, Gan, 22 November 2014 (GenBank accession number of 16S rRNA gene: MK231003). MBM189208, 19 male, 1.6-2.8 mm CL, 25 female, 1.8-4.7 mm CL, 36 ovigerous female, 2.6-5.0 mm CL, 11 juvenile 0.6-1.1 mm CL, same collection data as MBM189209; MBM189207, 1 ovigerous female, 3.8 mm CL, Hongtang bay, 
320

321

322

323

324

325

326

327

328

329

330

331

332

333

334

335

336

337

338

339

340

341

342

343

344

345

346

347

348

349

350

351

352

353

354

355

356

357

358

359

Hainan Island, northern South China Sea, 1-2 m, Coll. Z B. Gan, 22 March 2018 (GenBank accession number of 16S rRNA gene: MK231004); MBM189208, 3 male, 1.3-2.6 mm CL, 3 female, $1.5-3.9 \mathrm{~mm} \mathrm{CL}, 6$ ovigerous female, $2.5-4.7 \mathrm{~mm} \mathrm{CL}$, same collection data as MBM189207; MBM189206, 1 female, 3.5 mm CL, Luhuitou bay, Hainan Island, northern South China Sea, 1-2 m, Coll. Z B. Gan, 8 May 2015 (GenBank accession number of 16S rRNA gene: MK231009); MBM189205, 2 male, 2.0-2.6 mm CL, 1 female, $3.2 \mathrm{~mm} \mathrm{CL}, 4$ ovigerous female, 2.8-3.9 mm CL, same collection data as MBM189206; MBM189204, 5 male, 1.4-2.8 mm CL, 7 female, 1.4-4.0 mm CL, 9 ovigerous female, 2.2-4.5 mm CL, Dadonghai bay, Hainan Island, northern South China Sea, 2-3 m, Coll. Z B. Gan, 25 April 2016; MBM189203, 4 male, 1.1-2.9 $\mathrm{mm}$ CL, 9 female, 1.3-3.8 mm CL, 15 ovigerous female, $2.3-4.4 \mathrm{~mm} \mathrm{CL}, 2$ juvenile $0.6-0.9 \mathrm{~mm}$ CL, Yalong bay, Hainan Island, northern South China Sea, 1-3 m, Coll. Z B. Gan, 18 September 2017.

Remarks. These specimens had the following features: (1) first article of the antennular peduncle with one distolateral tooth, and fifth pleonite no dorsolateral tooth; (2) carapace length of mature females among 1.8-3.3 mm, and total length among 13-24 mm; (3) rostrum distinctly overreaching the end of the antennular peduncle but falling short of scaphocerite apex, superior border with 1-2 teeth and inferior border with 1-5 teeth; (4) incisor process of mandible with 5-6 teeth; (5) scaphocerite 2.79-3.38 times as long as wide; (6) dactyli of the third to fifth pereiopods with 2 large apical spines, but the longest apical spine never exceeding the half-length of dactyli properly, the ratio of the longest spine of dactylus/length of dactylus without spines among 0.330.41 ; (7) specimens displaying various colorations (Fig. 5F-G).

These features differ from those described for $H$. acuta, H. australiensis, H. ngi, $H$. singaporensis, and $H$. nanhaiensis sp. nov., but are similar to the morphological characters of $H$. ventricosa (referring to the redescription of D'Udekem d'Acoz, 1999). More than four cryptic or pseudocryptic species were recently detected using molecular markers, which were also morphologically very similar to $H$. ventricosa (De Grave et al., 2014; Terossi et al., 2017). Therefore, it is not clear which specimens represent the true $H$. ventricosa; 16S rRNA or other genetic data derived from the $H$. ventricosa topotype are expected to resolve this issue.

Coloration and Biotopes. Specimens captured among Thalassia sp. were generally bright green over body (Fig. 5F), or green over body with pink or brown stains on carapace, abdomen, and telson (Fig. 5J); specimens (Fig. 5G-I) captured among Sargassum sp. are generally sandy brown or reddish brown over body, with or without white stains on carapace, abdomen, and telson. All specimens were captured at depths of 1-3 m.

\section{Discussion}

Hippolyte chacei sp. nov. is distinguished from all other valid Hippolyte species by the unique dactylus of the third to fifth pereiopods. This type of dactylus has previously reported only for specimens attributed to $H$. ventricosa, such as those reported from the Malayan Archipelago (Holthuis, 1947), Madagascar (Ledoyer, 1970), and Hawai (Hayashi, 1981), which D’Udekem d'Acoz (1996) considered represented undescribed species. Our work, based on molecular data, 
360

361

362

363

364

365

366

367

368

369

370

371

372

373

374

375

376

377

378

379

380

381

382

383

384

385

386

387

388

389

390

391

392

393

394

395

396

397

398

399

confirms this suspicion. In the 16S rRNA phylogenetic tree (Fig. 10), H. chacei sp. nov. (two specimens) form an isolated branch clustered in the subbasal position of the Indo-West Pacific clade (Terossi et al., 2017). Additionally, the average genetic divergence between H. chacei sp. nov. and other Hippolyte species is $20.8 \%$, which is slightly greater than the average interspecific genetic divergence of $20.5 \%$ (calculated from the 30 Hippolyte species in our study).

Specimens attributed to $H$. ventricosa from the Malayan Archipelago and Madagascar by Holthuis (1947) and Ledoyer (1970) respectively, are very similar to H. chacei sp. nov. in morphology. We speculate that they are conspecific, but this speculation requires a detailed examination of their specimens. Hayashi (1981) stated that the mouthparts of Hawaiian specimens were similar to those of $H$. edmondsoni and $H$. jarvisensis, of which distinctly differ from those of $H$. chacei sp. nov.; moreover, difference is also apparent in the position of hepatic spine. Those specimens reported by Hayashi (1981) may represent a different species from $H$. chacei sp. nov.

Morphologically, $H$. nanhaiensis sp. nov. is similar to $H$. acuta, H. australiensis, $H$. ngi, $H$. singaporensis, and $H$. ventricosa (referring to the redescription of D'Udekem d'Acoz, 1999). They all have the first article of the antennular peduncle with one distolateral tooth, fifth pleonite without dorsolateral teeth, and third to fifth pereiopods with normal dactyli. H. nanhaiensis sp. nov. differs from H. acuta, H. australiensis, and H. ngi by its shorter rostrum (reaching to or only slightly overreaching the end of the antennular peduncle $v s$. distinctly overreaching the end of the antennular peduncle). H. acuta is further distinguished from H. nanhaiensis sp. nov. by its particularly long eyestalk (Stimpson, 1860; Hayashi \& Miyake, 1968; Yanagawa \& Watanabe, 1988; D'Udekem d'Acoz, 1996). H. australiensis is further distinguished from H. nanhaiensis sp. nov. by its rostrum, which has a sharp lateral carina, and also by the dactylus of the third to fifth pereiopods, which have four large apical spines (D'Udekem d'Acoz, 2001). H. ngi differs from $H$. nanhaiensis sp. nov. by its hepatic, which overreaches the anterior edge of carapace by distal half length, and also by the dactylus of the third to fifth pereiopods, which have three large apical spines (Gan \& Li, 2017b).

According to D'Udekem d'Acoz (1999), H. ventricosa also has two large apical spines on the dactylus of the third to fifth pereiopods, although the apical spines of $H$. nanhaiensis sp. nov. are proportionally longer. The ratio of the longest spine of the dactylus/length of the dactylus without spines is $0.53-0.58$ in $H$. nanhaiensis sp. nov., but it is only 0.35 in $H$. ventricosa. The rostrum of $H$. ventricosa distinctly overreaches the end of the antennular peduncle, but it only reaches to or slightly overreaches the end of the antennular peduncle in H. nanhaiensis sp. nov. The scaphocerite of $H$. ventricosa is 3.10 times as long as wide, but it is $2.19-2.38$ times as long as wide in $H$. nanhaiensis sp. nov. The total length of the $H$. ventricosa syntypes reaches $17 \mathrm{~mm}$ (D’Udekem d'Acoz, 1999), nearly two times longer than the largest $H$. nanhaiensis sp. nov. Furthermore, the two species inhabit different ecological niches. H. ventricosa lives among Zostera sp. or Padina sp., and may also be found among Sargassum sp., but H. nanhaiensis sp. nov. was found only among Galaxaura sp. or Halimeda sp., and no other congeners were found in these biotopes. 
400 In the 16S rRNA phylogenetic tree (Fig. 10), H. nanhaiensis sp. nov. (two specimens) form a 401 clade with $H$. ventricosa group-sp. 4 (Terossi et al., 2017), with this clade being a sister to $H$. 402 australiensis. The average genetic divergence between $H$. nanhaiensis sp. nov. and other 403 Hippolyte species is $22.5 \%$, which is greater than the average interspecific genetic divergence 404 (20.5\%). 16S rRNA sequence alignment reveals $H$. nanhaiensis sp. nov. to be identical to, or to 405 has a single nucleotide base difference from specimen of $H$. ventricosa group-sp. 4 (KX588916). 406 Therefore, the specimen attributed to $H$. ventricosa group-sp. 4 and $H$. nanhaiensis sp. nov. 407 might ultimately prove to be conspecific.

408

\section{Conclusions}

410 As noted by D'Udekem d'Acoz (1999; 2001), the systematics of Indo-West Pacific Hippolyte is 411 extremely complicated, even though this region is considered the origin center of the genus 412 (Terossi et al., 2017). Much of this taxonomic confusion stems from a lack of knowledge of 413 several species, such as $H$. proteus, $H$. kraussiana, and $H$. acuta, and the plasticity in 414 morphological characters of deemed taxonomic importance. Our study demonstrate the length of 415 the rostrum relative to the antennular peduncle, the ratio of width to height of the scaphocerite, 416 the position of the hepatic spine, and the features of the dactylus of the third to fifth pereiopods 417 to be taxonomic value. A preliminary key for the indentification of mature female of the genus 418 Hippolyte occurring in the Indo-West Pacific and neighboring seas is provided. This key only 419 contains valid species listed in WoRMS (http://www.marinespecies.org); the cryptic or pseudocryptic $H$. ventricosa species are temporarily pooled as ' $H$. ventricosa' sensu lato.

Key to mature female of Hippolyte for the Indo-West Pacific and neighboring seas 2a-Merus of third pereiopod with no more than one lateral spine, scaphocerite about 2.8 times as long as wide. H. proteus 2b-Merus of third pereiopod with 3-5 lateral spines, scaphocerite about 3.5 times as long as wide. .H. kraussiana 3a-Dactyli of third to fifth pereiopods slender, simple, with elongate curved unguis, without ventral spines, mainly associated with Alcyonacean corals. 3b-Dactyli of third to fifth pereiopods with obvious ventral or subdorsal spines, mainly inhabited 4a-Carapace with dorsal surface strongly gibbous, fingers of first pereiopod about half as long as palm. .H. dossena 4b-Carapace with dorsal surface flat, non-gibbous, fingers of first pereiopod subequal to palm. H. commensalis 
439 6a-Rostrum less than half length of carapace, reaching to the end of first segment of antennular 440 peduncle at most.......................................................... edmondsoni

441 6b-Rostrum longer than the half length of carapace, reaching to the end of antennular



443 7a-Rostrum without dorsal tooth, base of hepatic spine nearly situating at anterior edge of

444

445

446

447

448

449

450

451

452

453

454

455

456

457

458

459

460

461

462

463

464

465

466

467

468

469

470

471

472

473

474

475

476

477

carapace. H. singaporensis

7b-Rostrum with 1-2 dorsal teeth, base of hepatic spine situating at posterior to the anterior edge of carapace. .8 8a-Distal spine of dactylus of third pereiopod longer than the half length of dactylus proper (excluding spines)

8b-Distal spine of dactylus of third pereiopod shorter than the half length of dactylus proper (excluding spines). H. jarvinensis 9a-Rostrum with postrostral spine, situating at just above the orbit. H.caradina 9b-Rostrum without postrostral spine, all dorsal spines situating at prior to the orbit. H. nanhaiensis sp. nov.

10a-Incisor process of mandible with no more than 8 acute teeth 11

10b-Incisor process of mandible with 15-17 acute teeth, dactyli of third to fifth pereiopods with 2-3 subdorsal spines. H. chacei sp. nov.

11a-Unpigmented part of eyestalk 3 times as long as cornea........................... H. acuta

$11 \mathrm{~b}$-Unpigmented part of eyestalk no more than 3 times as long as cornea......................12



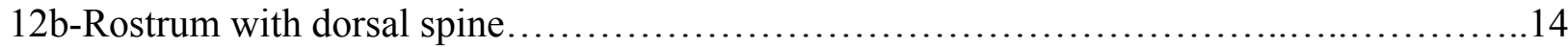

13a-Apex of the rostrum trifid................................................. multicolorata

13b-Apex of rostrum simple.......................................................... australiensis

14a-Apex of the Rostrum bifid.................................................... bifidirostris

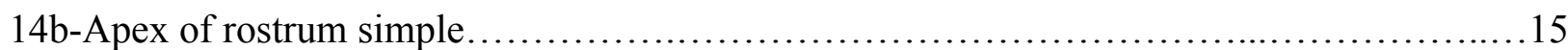

15a-Dactyli of third to fifth pereiopods with three long terminal teeth, distal half of hepatic spine overreaching anterior edge of carapace. H. $n g i$ 15b-Dactyli of third to fifth pereiopods with two terminal teeth, hepatic spine slightly overreaching anterior edge of carapace. H. ventricosa sensu lato

\section{Acknowledgements}

We are extremely grateful to Dr. Xinming Liu (Guangxi Academy of Oceanography) and Dr. Dong Dong (Institute of Oceanology, Chinese Academy of Sciences) for their kind help with photographing the specimens, and sincere thanks are extended to associate professor Yuanchao Li (Hainan Academy of Ocean and Fisheries Sciences) for his great help in the sample collection in the Xisha Islands.

\section{References}


478 Castresana J. 2000. Selection of conserved blocks from multiple alignments for their use in

479

480

481

482

483

484

485

486

487

488

489

490

491

492

493

494

495

496

497

498

499

500

501

502

503

504

505

506

507

508

509

510

511

512

513

514

515

516

517

phylogenetic analysis. Molecular Biology and Evolution 17(4): 540-552.

Crandall KA, Fitzpatrick JF Jr. 1996. Crayfish molecular systematics: using a combination of procedures to estimate phylogeny. Systematic Biology 45(1): 1-26.

De Grave S, Li CP, Tsang LM Chu KH, Chan T-Y. 2014. Unweaving hippolytoid systematics (Crustacea, Decapoda, Hippolytidae): resurrection of several families. Zoologica Scripta 43(5): 496-507.

Duarte C, Flores AA. 2017. Morph-specific habitat and sex distribution in the caridean shrimp Hippolyte obliquimanus. Journal of the Marine Biological Association of the United Kingdom 97(2): 235-242.

Duarte RC, Flores AA, Vinagre C, Leal MC. 2017. Habitat-dependent niche partitioning between colour morphs of the algal-dwelling shrimp Hippolyte obliquimanus. Marine Biology 164(11): 215.

D'Udekem d'Acoz C. 1996. The genus Hippolyte Leach, 1814 (Crustacea: Decapoda: Caridea: Hippolytidae) in the East Atlantic Ocean and the Mediterranean Sea, with a checklist of all species in the genus. Zoologische Verhandelingen 303: 1-133.

D’Udekem d'Acoz C. 1999. Redescription of Hippolyte ventricosa H. Milne Edwards, 1837 based on syntypes, with remarks on Hippolyte orientalis Heller, 1862 (Crustacea, Decapoda, Caridea). Zoosystema 21(1): 65-76.

D'Udekem d'Acoz C. 2001. Redescription of Hippolyte australiensis (Stimpson, 1860) (Crustacea, Decapoda, Caridea). Biologie 71: 37-44.

D'Udekem d'Acoz C. 2007. New records of Atlantic Hippolyte, with the description of two new species, and a key to all Atlantic and Mediterranean species (Crustacea, Decapoda, Caridea). Zoosystema 29(1): 183-207.

Edgar RC. 2004. MUSCLE: multiple sequence alignment with high accuracy and high throughput. Nucleic Acids Research 32(5): 1792-1797.

Gan ZB, Li XZ. 2017a. A new species of the genus Hippolyte (Decapoda: Caridea: Hippolytidae) from South China Sea and Singapore. Zootaxa 4258(1): 34-42.

Gan ZB, Li XZ. 2017b. A new species of the genus Hippolyte (Decapoda: Caridea: Hippolytidae) from Singapore. Raffles bulletin of zoology 65: 207-212.

Guindon S, Gascuel O. 2003. A simple, fast, and accurate algorithm to estimate large phylogenies by maximum likelihood. Systematic Biology 52(5): 696-704.

Hayashi KI. 1986. An annotated list of shrimps (Alpheidae and Palaemonidae excluded) collected from the Gilbert and Solomon Islands. Proceedings of the Japanese Society of Systematic Zoology 32: 17-29.

Hayashi KI. 1981. The Central Pacific shrimps of the genus Hippolyte, with a description of two new species (Decapoda, Caridea, Hippolytidae). Pacific Science 35(3): 185-196.

Hayashi KI, Miyake S. 1968. Studies on the hippolytid shrimps from Japan, V. Hippolytid fauna of the sea around the Amakusa Marine Biological Laboratory. Ohmu [Occasional papers of Zoological Faculty of Agriculture, Kyushu University, Fukuoka, Japan] 1(6): 121-163. 
518 Holthuis LB. 1947. The Hippolytidae and Rhynchocinetidae collected by the Siboga and Snellius 519 Expedition with remarks on other species. Siboga Expeditie Monographie 39a: 1-100.

520 Huelsenbeck JP, Ronquist F. 2001. MRBAYES: Bayesian inference of phylogeny. Biometrics 521 17: 754-755.

522 Kumar S, Stecher G, Tamura K. 2016. MEGA7: molecular evolutionary genetics analysis 523 version 7.0 for bigger datasets. Molecular biology and evolution 33(7): 1870-1874.

524 Ledoyer M. 1970. Étude systématique et remarques écologiques sur les Caridea recueillis 525 principalement dans les biotopes de substrat meuble régions de Tuléar et de Nosy-Bé. Annales

526

527

528

529

530

531

532

533

534

535

536

537

538

539

540

541

542

543

544

545

546

547

548

549

550

551

552 de l'Université de Madagascar série Sciences de la nature et Mathématiques 7: 121-157.

Liasko R, Anastasiadou C, Ntakis A. 2018. Eco-morphological consequences of the 'rostral loss' in the intertidal marine shrimp Hippolyte sapphica morphotypes. Journal of the Marine Biological Association of the United Kingdom 98(7): 1667-1673.

Liasko R, Anastasiadou C, Ntakis A, Leonardos ID. 2015. How a sharp rostral dimorphism affects the life history, population structure and adaptability of a small shrimp: the case study of Hippolyte sapphica. Marine Ecology 36(3): 400-407.

Manjón-Cabeza ME, Cobos V, Raso JEG. 2011. The reproductive system of Hippolyte niezabitowskii (Decapoda, Caridea). Zoology 114(3), 140-149.

Marin I, Okuno J, Chan T-Y. 2011. On the "Hippolyte commensalis Kemp, 1925" species complex (Decapoda, Caridea, Hippolytidae), with the designation of a new genus and description of two new species from the Indo-West Pacific. Zootaxa 2768: 32-54.

Posada D, Crandall KA. 1998. Modeltest: testing the model of DNA substitution. Bioinformatics 14(9): 817-818.

Stimpson W. 1860. Prodromus descriptionis animalium evertebratorum, quae in Expeditione ad Oceanum Pacificum Septentrionalem, a Republica Federate missa, Cadwaladaro Ring-gold et Johanne Rodgers Ducibus, observavit et descripsit. Pars V. Crustacea Ocypodoidea. Proceedings of the Academy of Natural Sciences of Philadelphia 12: 22-47.

Terossi M, De Grave S, Mantelatto FL. 2017. Global biogeography, cryptic species and systematic issues in the shrimp genus Hippolyte Leach, 1814 (Decapoda: Caridea: Hippolytidae) by multimarker analyses. Scientific reports 7(1): 6697.

Terossi M, Mantelatto FL. 2012. Morphological and genetic variability in Hippolyte obliquimanus Dana, 1852 (Decapoda, Caridea, Hippolytidae) from Brazil and the Caribbean Sea. Crustaceana 85(6): 685-712.

Yanagawa SL, Watanabe S. 1988. Life history and morphology of the hippolytid shrimp Hippolyte ventricosa in Kominato bay. Bulletin of the Japanese Society of Scientific Fisheries 54(4): 613-618. 
Figure 1

Hippolyte chacei sp. nov. female, holotype.

Hippolyte chacei sp. nov. female, holotype, MBM285015, lateral view. Scale: $1.0 \mathrm{~mm}$.

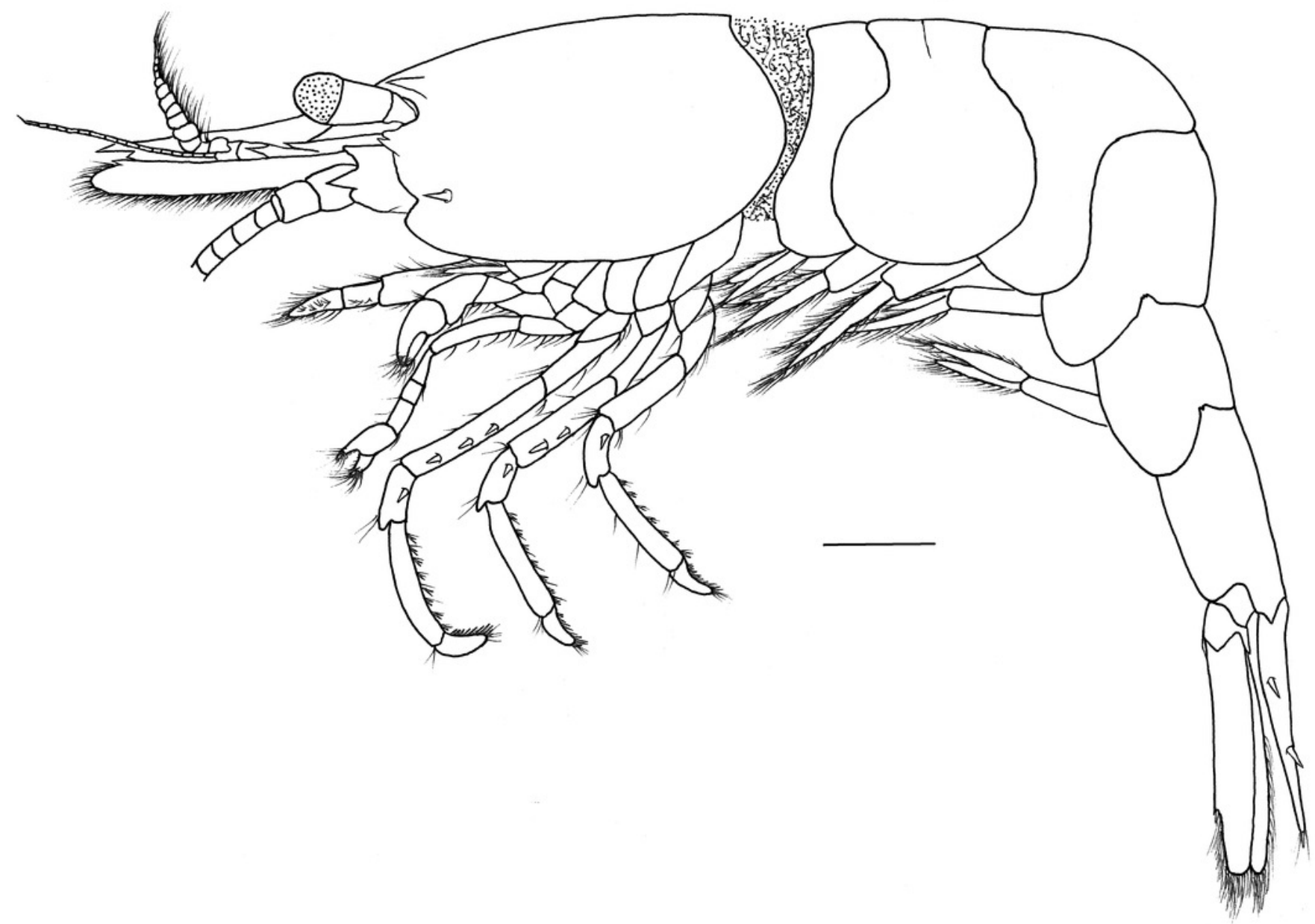


Figure 2

Cephalon and telson of Hippolyte chacei sp. nov.

Hippolyte chacei sp. nov. A, B, D-H, female, holotype, MBM285015; C, male, paratype, MBM285016. A, cephalon, dorsal; B, carapace and rostrum, lateral; C rostrum, lateral; D, inferior orbital angle, dorsal; E, telson and uropods, dorsal; F, right antennula, dorsal; G, first segment of right antennule, ventral; $H$, right scaphocerite, dorsal. Scales: $1.0 \mathrm{~mm}$.

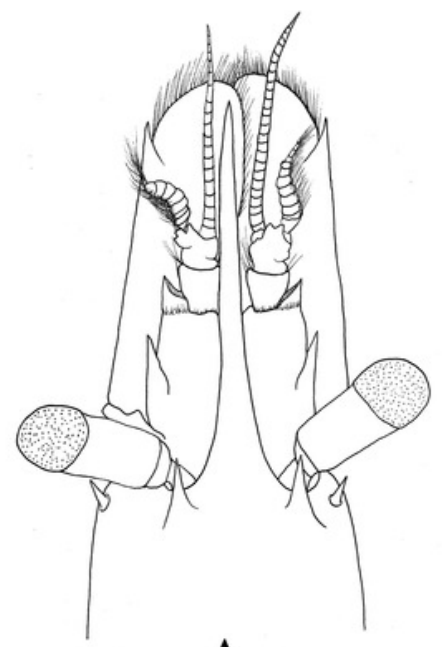

A

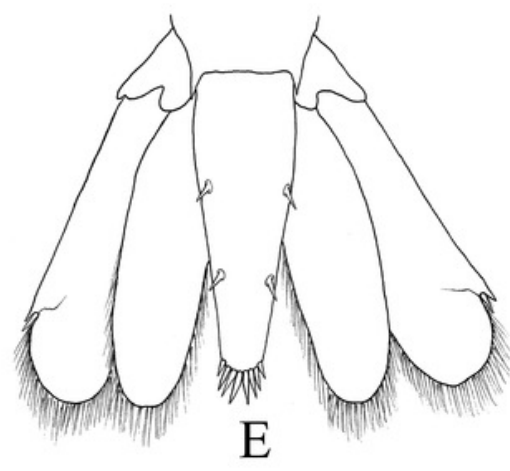

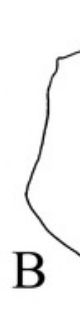
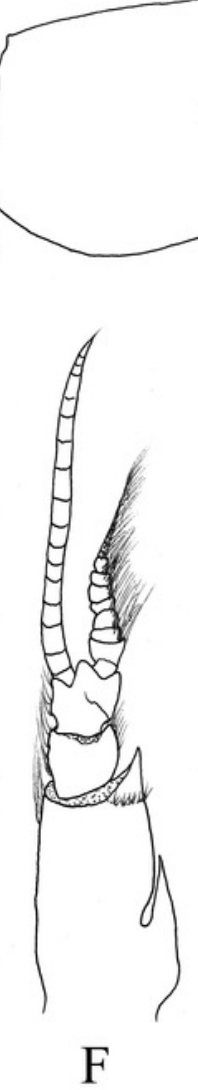

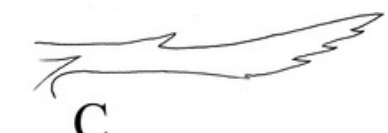

$\mathrm{C}$

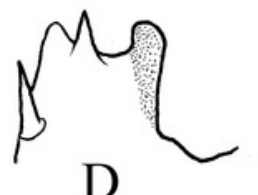

$\mathrm{D}$

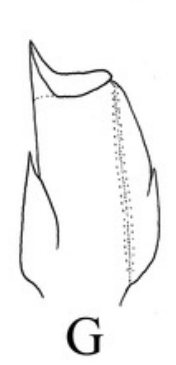

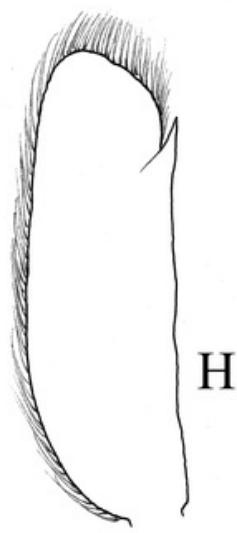

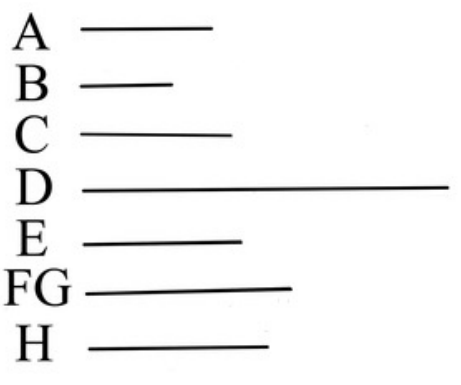


Figure 3

Mouthparts of Hippolyte chacei sp. nov.

Hippolyte chacei sp. nov. female, holotype, MBM285015. A, B, left mandible; C, left maxillule;

D, left maxilla; E, left first maxilliped; F, left second maxilliped; G, left third maxilliped. Scale:

$1.0 \mathrm{~mm}$.

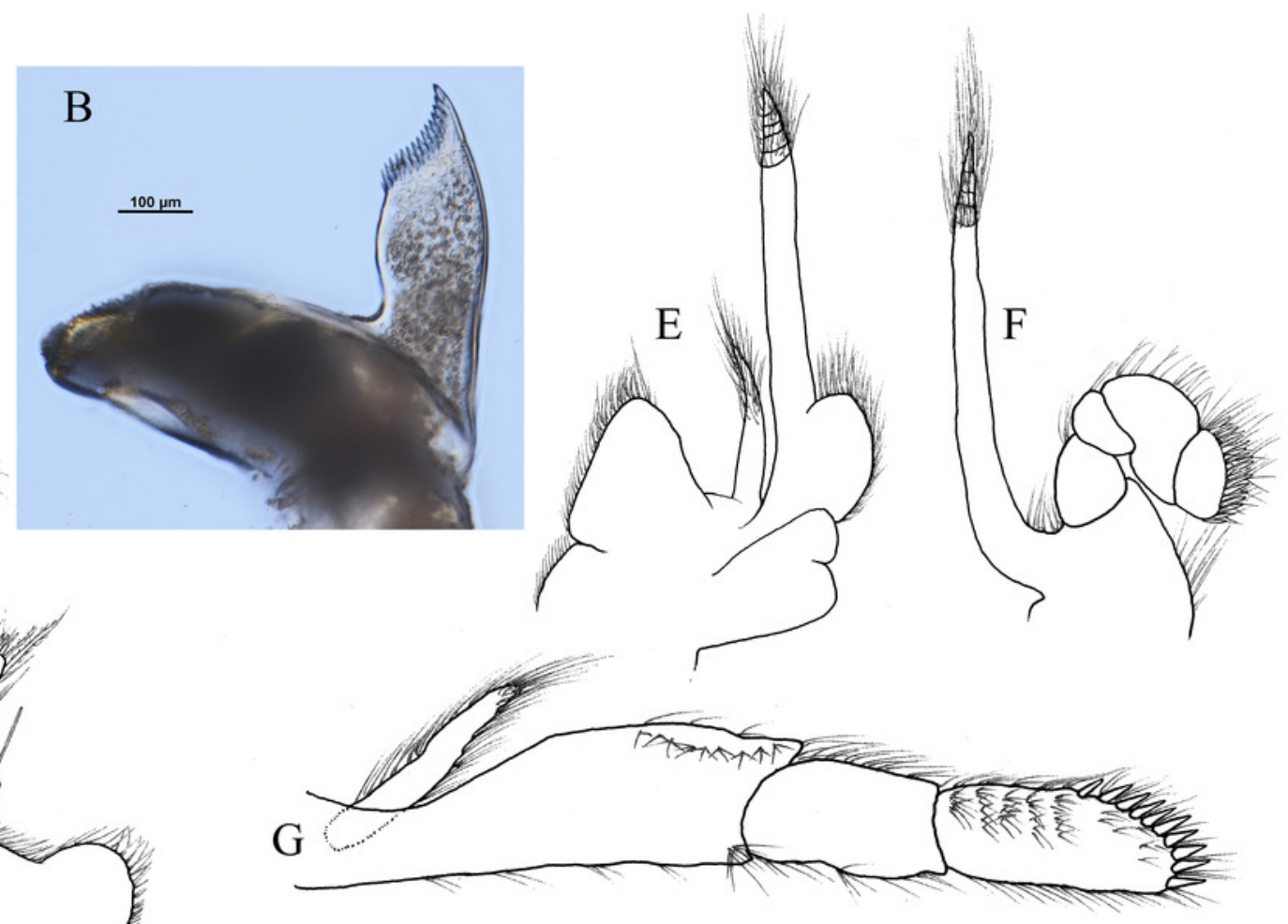

ACDEFG 


\section{Figure 4}

Pereiopods and pleopods of Hippolyte chacei sp. nov.

Hippolyte chacei sp. nov. A-F, I-M, female, holotype, MBM285015; G, H, N-P, male, paratype, MBM285016. A, left first pereiopod, lateral; B, tip of the left first pereiopod, mesial (setae not shown); C, left second pereiopod, lateral; D, tip of the left second pereiopod, mesial (setae not shown); E, left third pereiopod, lateral; F, dactylus of left third pereiopod, lateral; G, H, propodus and dactylus of left third pereiopod, lateral; I, left fourth pereiopod, lateral; J, dactylus of left fourth pereiopod, lateral; K, left fifth pereiopod, lateral; L, dactylus of left fifth pereiopod, lateral; $M, N$, left first pleopod; $\mathrm{O}$, left second pleopod; $\mathrm{P}$, appendix masculina. Scales: A, C, E, G, I, K, M-O, 1 mm; B, D, $100 \mu \mathrm{m}$. 







\section{Figure 5}

Photos of Hippolyte spp. collected from Hainan Island and the Xisha Islands.

Photos of Hippolyte spp. collected from Hainan Island and the Xisha Islands. A, Hippolyte chacei sp. nov.; B-E, Hippolyte nanhaiensis sp. nov.; F-G, Hippolyte cf. ventricosa. Scale: 1.0 $\mathrm{mm}$.




Figure 6

Hippolyte nanhaiensis sp. nov. ovigerous female, holotype.

Hippolyte nanhaiensis sp. nov. ovigerous female, holotype, MBM285018, lateral view. Scale: $1.0 \mathrm{~mm}$.

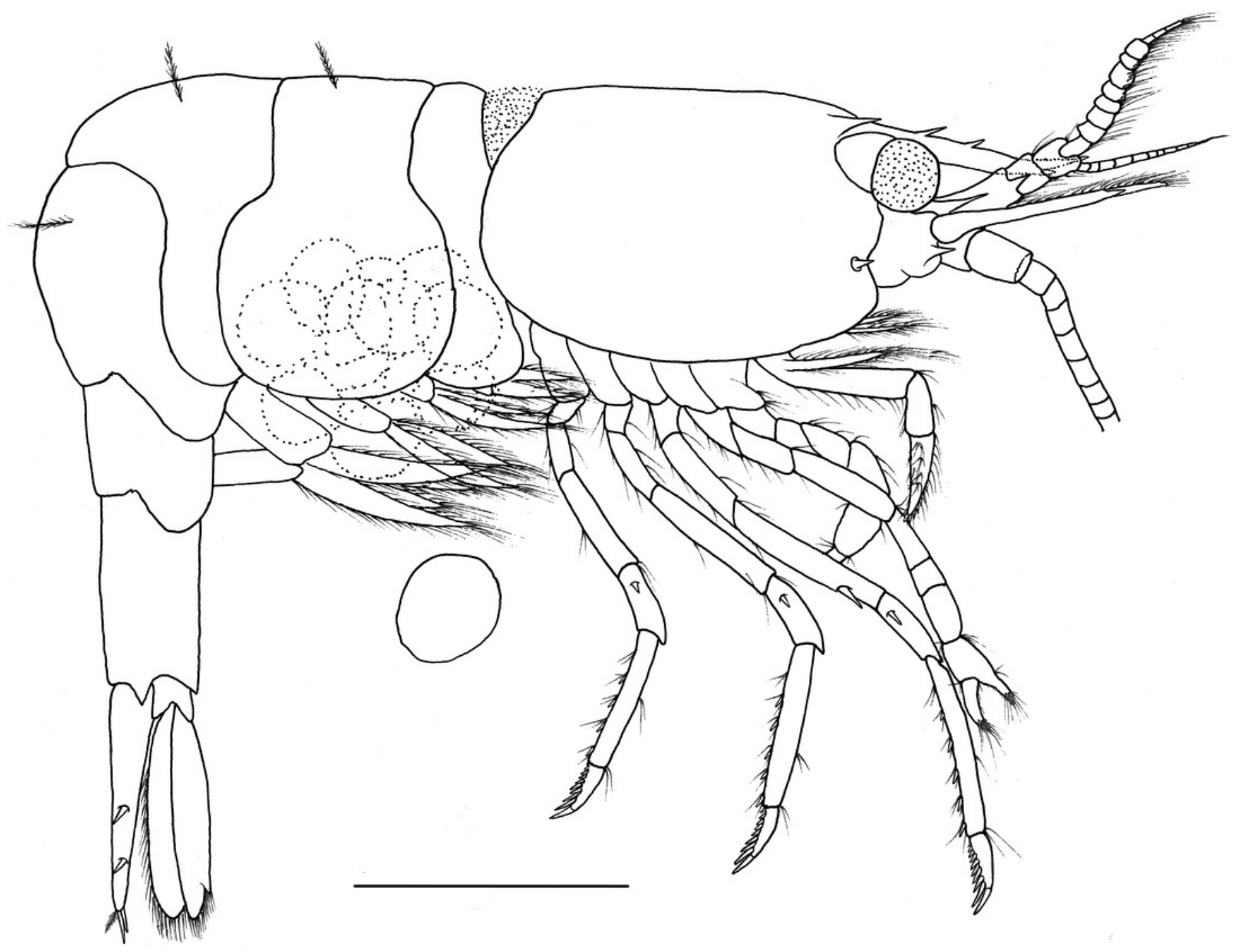


Figure 7

Cephalon and telson of Hippolyte nanhaiensis sp. nov.

Hippolyte nanhaiensis sp. nov. A-C, E-H, ovigerous female, holotype, MBM285018; D, male, paratype, MBM285019. A, cephalon, dorsal; B, anterior of rostrum, dorsal; C, carapace and rostrum, lateral; D, rostrum, lateral; E, telson and uropods, dorsal; $F$, right antennula, dorsal; $\mathrm{G}$, first segment of right antennule, ventral; $\mathrm{H}$, right scaphocerite, dorsal. Scales: $1.0 \mathrm{~mm}$.
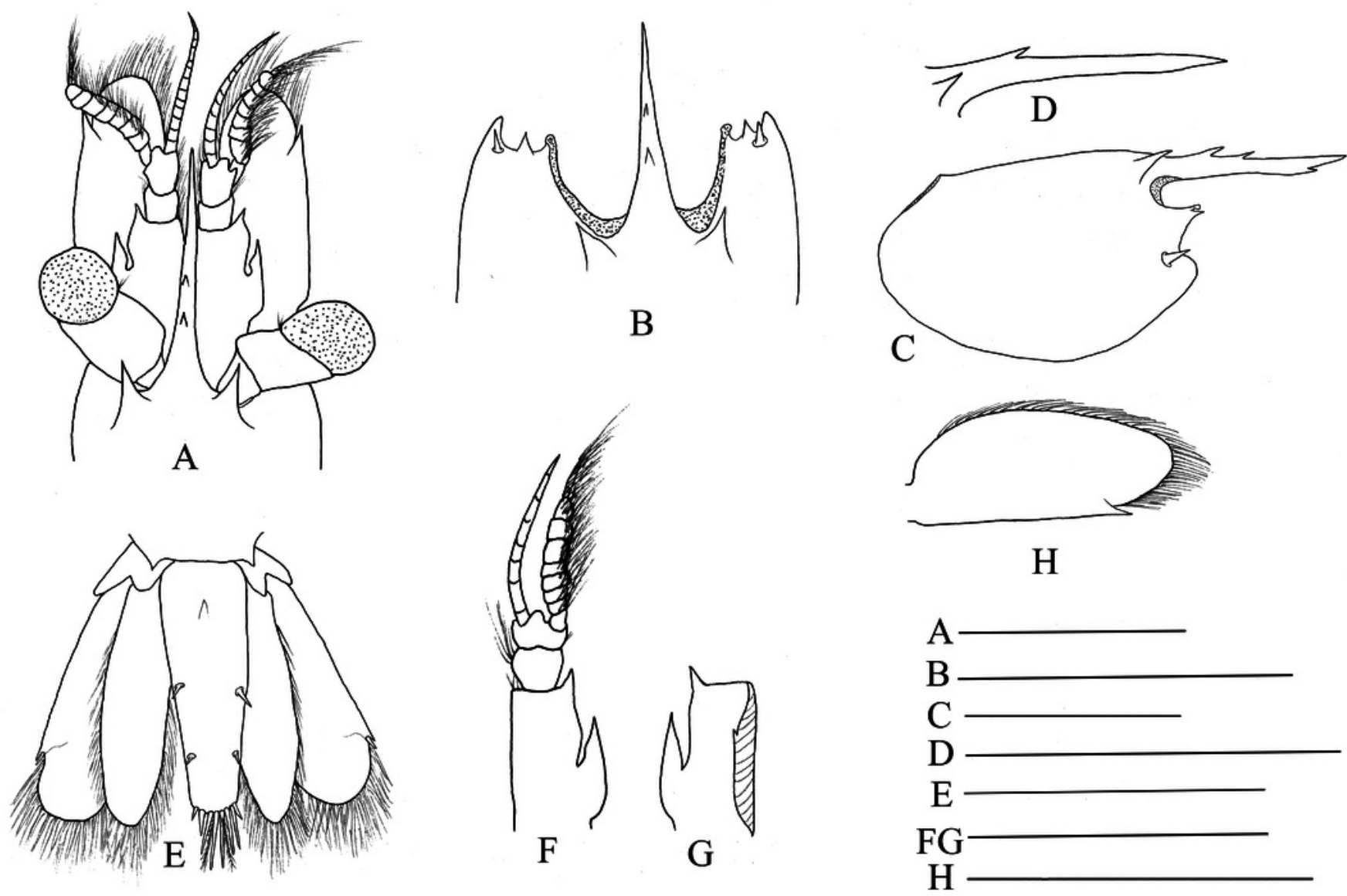
Figure 8

Mouthparts of Hippolyte nanhaiensis sp. nov.

Hippolyte nanhaiensis sp. nov. ovigerous female, holotype, MBM285018. A, left mandible; B, left maxillule; C, left maxilla; $D$, left first maxilliped; $E$, left second maxilliped; $F$, left third maxilliped. Scale: $1.0 \mathrm{~mm}$.
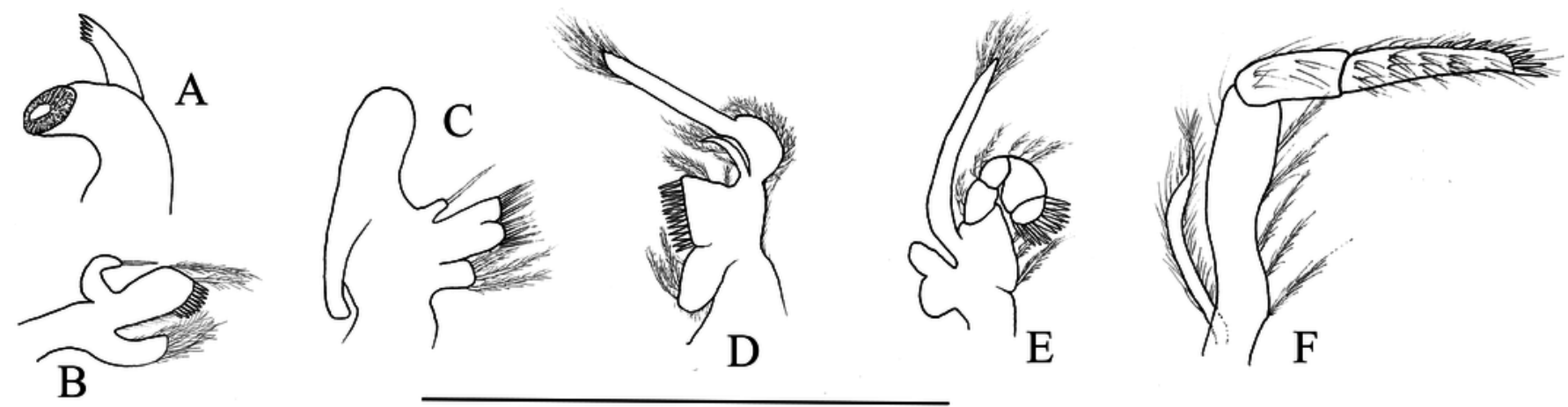


\section{Figure 9}

Pereiopod and pleopods of Hippolyte nanhaiensis sp. nov.

Hippolyte nanhaiensis sp. nov. A-F, I-K, female, holotype, MBM285018; G, H, L-N, male, paratype, MBM285019. A, right first pereiopod, lateral; B, tip of the left right pereiopod, mesial (setae not shown); C, right second pereiopod, lateral; D, tip of the right second pereiopod, mesial (setae not shown); E, right third pereiopod, lateral; F, dactylus of right third pereiopod, lateral; G, H, propodus and dactylus of right third pereiopod, lateral; I, right fourth pereiopod, lateral; J, right fifth pereiopod, lateral; K, L, left first pleopod; $M$, right second pleopod; N, appendix masculina. Scales: A, C, E, G, I-M, 1 mm; B, D, $100 \mu \mathrm{m}$. 

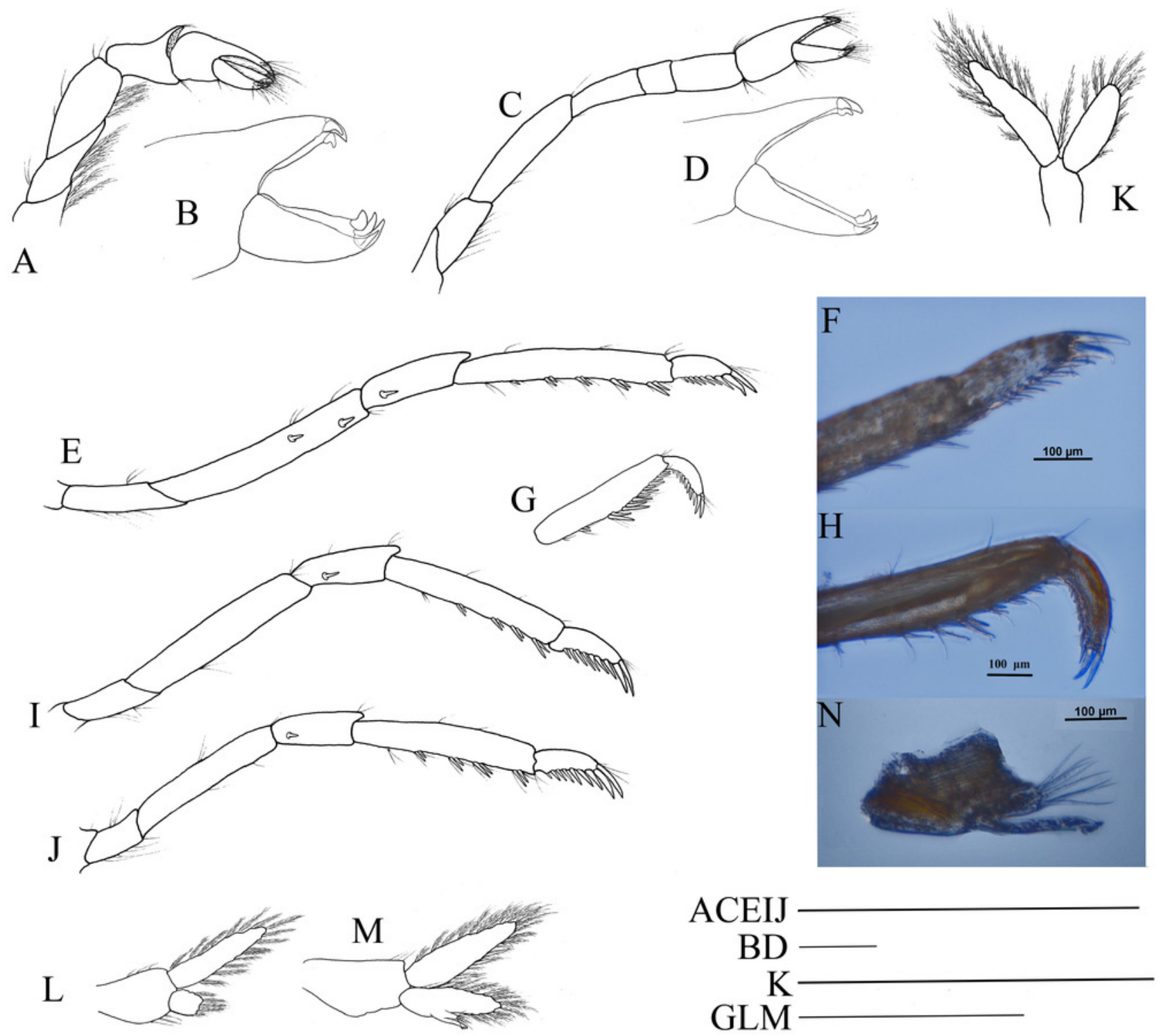


\section{Figure 10}

\section{S rRNA phylogenetic tree.}

\section{Maximum likelihood tree based on 16S rRNA sequence data. Numbers at nodes represent}

posterior probabilities/bootstrap values (BI/ML), numbers less than 50 or 0.50 are not shown.

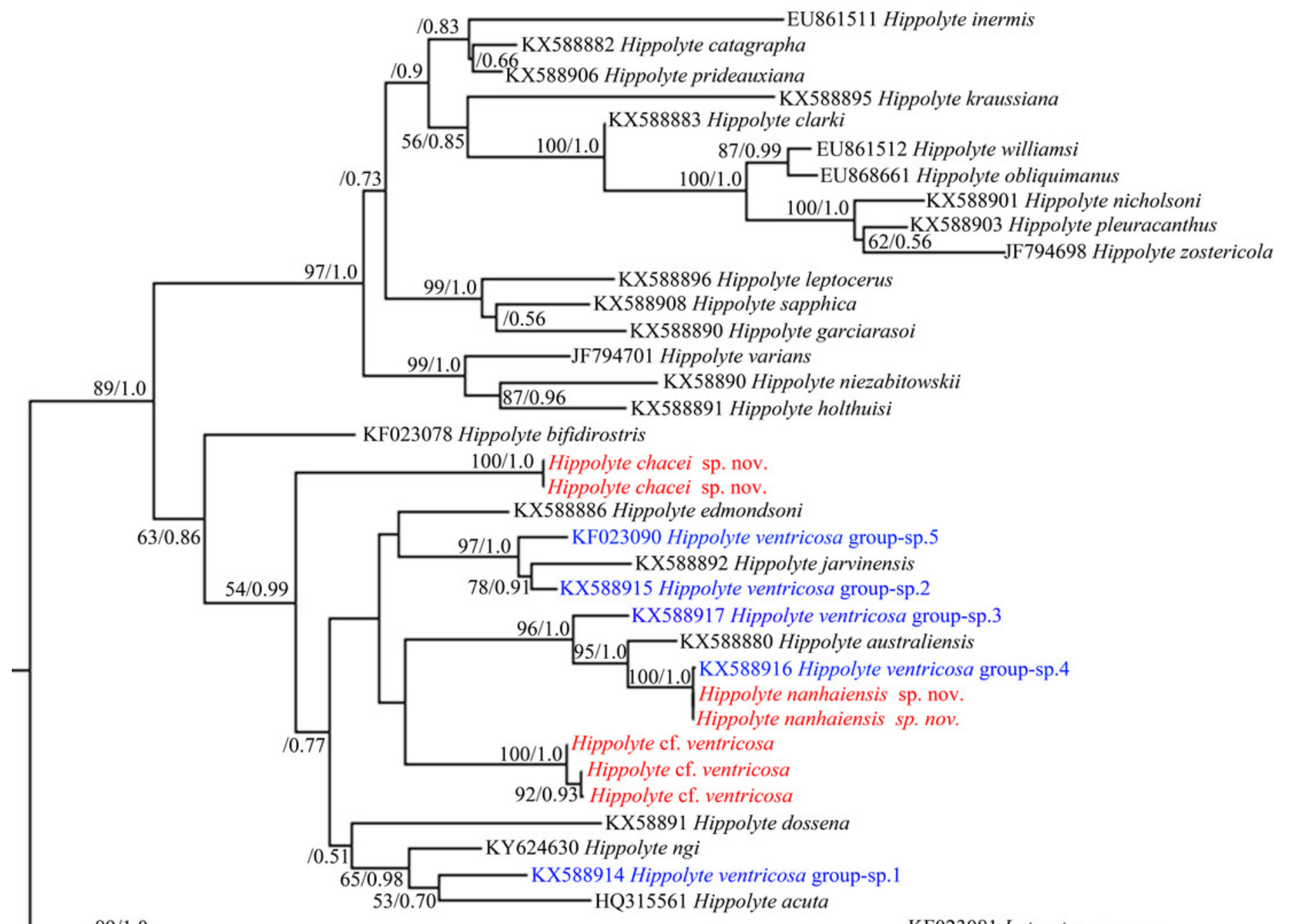

$89 / 1.0$

KF023185 Tozeuma lanceolatum

KF023081 Latreutes pymoeus

0.2 


\section{Table 1 (on next page) \\ Information on biodiversity}

The information on biodiversity surveys 
1

\begin{tabular}{|l|l|l|}
\hline Sampling locality & Investigation date & Botopes \\
\hline Hainan island & 20 Nov 2014-01 Dec 2014 & Sargassum sp. and Zostera sp. \\
\hline Hainan island & 04 May 2015-10 May 2015 & Sargassum sp. and Zostera sp. \\
\hline Hainan island & 22 Apr 2016-27 Apr 2016 & Sargassum sp. and Zostera sp. \\
\hline Hainan island & 16 Sep 2017-22 Sep 2017 & Sargassum sp. and Zostera sp. \\
\hline Hainan island & 20 Mar 2018-28 Mar 2018 & Sargassum sp. and Zostera sp. \\
\hline Xisha islands & 12 May 2015-19 May 2015 & Galaxaura sp. and Halimeda sp. \\
\hline Xisha islands & 10 Jul 2016-20 Jul 2016 & Galaxaura sp. and Halimeda sp. \\
\hline
\end{tabular}

2 


\section{Table 2 (on next page)}

Specimens information.

Specimens collected in this study with reference to their locality, Voucher ID, and GenBank accession numbers. 
1

\begin{tabular}{|l|l|l|l|}
\hline Species & Sampling locality & Voucher ID & GenBank accession numbers \\
\hline Hippolyte cf. ventricosa & Hainan island & MBM285012 & MK231003 \\
\hline Hippolyte cf. ventricosa & Hainan island & MBM285013 & MK231004 \\
\hline Hippolyte cf. ventricosa & Hainan island & MBM285014 & MK231009 \\
\hline Hippolyte chacei sp. nov. & Hainan island & MBM285015 & MK231007 \\
\hline Hippolyte chacei sp. nov. & Hainan island & MBM285016 & MK231008 \\
\hline Hippolyte nanhaiensis sp. nov. & Xisha islands & MBM285018 & MK231005 \\
\hline Hippolyte nanhaiensis sp. nov. & Xisha islands & MBM285019 & MK231006 \\
\hline
\end{tabular}

2 